\section{LANDSCAPE TERMS OF THAI COAST-DWELLERS ${ }^{1}$}

\author{
Sunee Kamnuansin ${ }^{2}$
}

\begin{abstract}
This paper examines terms and classification of landscape among coastdwellers who earn a living by exploiting marine resources. It is based on fieldwork conducted from the end of 2009 to the end of 2010 with a group of local Thai coastal dwellers in Bang Khunsai Subdistrict, Ban Laem District in Phetchaburi Province. Data collection involved interviews and observation, especially during fieldwalking in the area with the locals. An analysis of componential meaning and folk taxonomy is applied for this study. Landscape terms reflect the coast-dwellers' perceptions and classification system of their natural environments and enable us to understand the local ecological knowledge, a crucial knowledge base for management, utilization, and conservation of marine resources. It is also seen as an important part of their cultural heritage.
\end{abstract}

\section{Introduction}

Landscape terms used by various groups who live in close contact with nature, have been researched in studies conducted by, among others, Mark and Turk (2003),

\footnotetext{
1 This paper is based on my doctoral dissertation of 2012. I wish to acknowledge Prof. Suwilai Premsrirat, my major advisor, for guidance and support, and the Office of the Higher Education Commission for the Ph.D. scholarship.

2 Lecturer, Faculty of Management Science, Silpakorn University, Phetchaburi IT campus
}

Burenhult (2005), O'Meara and Bohnemeyer (2008) and O'Connor and Kroefges (2008). The work of these noted linguists investigated the relationship between language, geographic reality and human cognition. This current study furthers these investigations by focusing on landscape terms used by coast-dwellers with an emphasis on the people in a geographic area and region that is particularly unique and outstanding for its ecological diversity.

In the seaside provinces of Thailand, there are several coastal communities where dwellers have a way of life which depends on the sea; they mainly earn their living from marine resources. The area of this study, Bang Khunsai Subdistrict of Ban Laem District in Phetchaburi Province, is an area with several traditional coastal villages and great ecological diversity. The eastern part of the subdistrict meets the upper Gulf of Thailand. It now consists of 11 villages in an area of about 15,732 rai $(25.7 \mathrm{sq} \mathrm{km}$ ) made up of plains and coastal plains. 


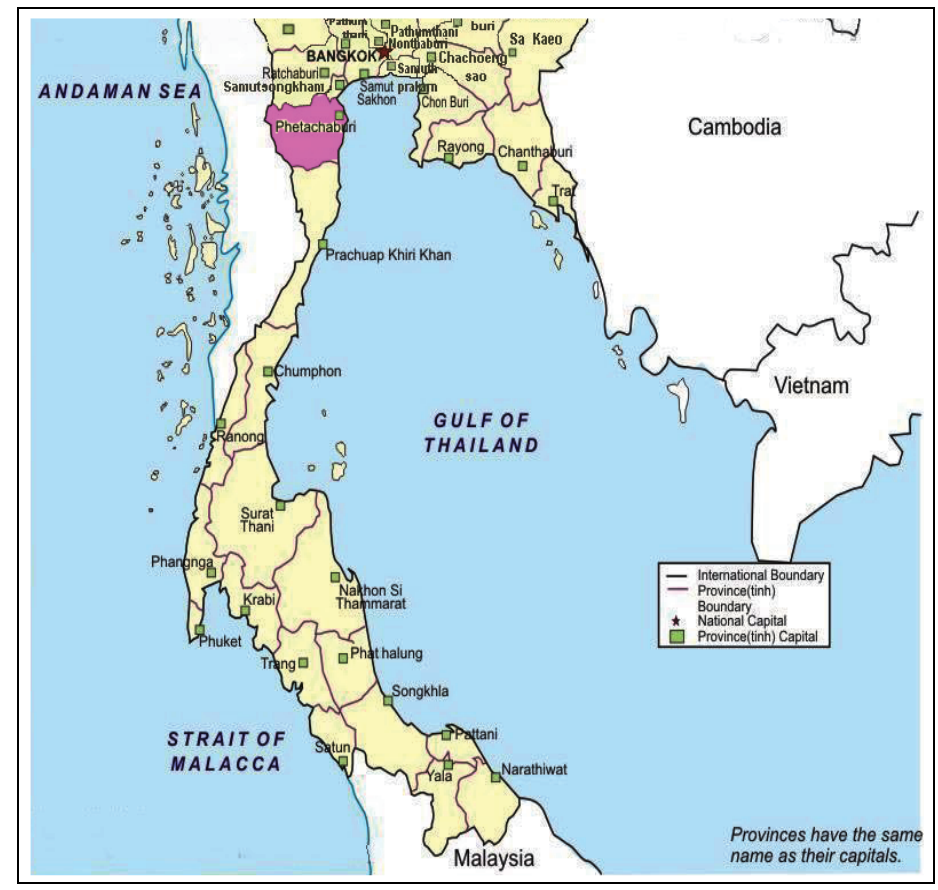

Map 1 Location of Phetchaburi Province and neighboring coastal provinces

The coastal area is dominated by mangrove forests with trees mostly of the genus Avicennia called /samě:/ (แสม) and the genus Rhizophora called /ko:yka:y/ (โกงกาง). These 'mangrove trees' stretch about 10 kilometers along the shore of the subdistrict and expand out about 100-150 meters from the shore into the sea. This is a conservation area. Next to the mangrove forest is a mudflat about 3 kilometers wide stretching into the sea at the lowest tide. The mudflats, once underwater, are exposed approximately 6-9 hours in the day. The area is the breeding ground and food source for various marine animals living there such as cockles, wedge shells, crabs, shrimps, mullets and others. It is claimed to be Thailand's biggest natural habitat for blood cockles.

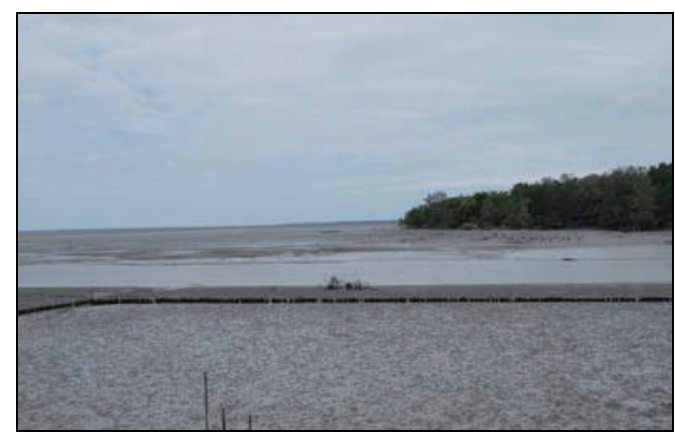

Figure 1 The mudflats area at low tide

Apart from the diversity of ecological features, a diversity of ethnicities is also found in Bang Khunsai Subdistrict. According to the long oral history recreated by the locals, the Chinese were the first group of people to settle in the Bang Khunsai area to take advantage of the abundant resources and the fact that the seaside area was suitable for fisheries. 
Later, Muslims, as well as Lao Phuan, Lao Wiang, and nearby local people came to settle in the area. Nowadays, many traditions and cultures have been combined and blended into a mutual local Thai culture. This includes the language itself which is Central Thai with a local Phetchaburi accent.

Most of the local villagers living in the seaside villages of Moo 1, 2, 3, 4, 8 and Moo 10 are employed in small-scale coastal fishing using mud-skiing (sliding boards) to pick blood cockles and wedge shells, trapping sergestid shrimp known as $/ \mathrm{k}^{\mathrm{h}}$ ə:y/ (เคย), and using boats to catch shrimp, crabs and fish. Some work as employees on big fishing boats. Fishing skills are transferred among individuals in the family. Only some families work in the salt fields in the inner land.

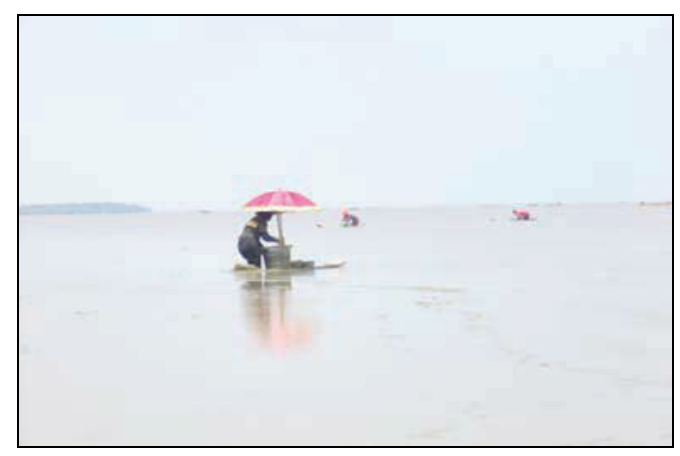

Figure 2 Villagers use mud-skiing techniques for catching blood cockles along the mudflats

\section{Brief on data collection and analysis}

Data collection mainly focused on the Moo 2 village, named "Ban Bang Khunsai". This village is unquestionably a traditional community on the coast and was among the first villages formed in the Bang Khunsai subdistrict. Seven locals, aged at least 35 years with good indigenous knowledge and earning their living in the area, were selected as key informants. Data was also elicited from several other members of the community, not only from the key informants.

Field interviews were conducted on several occasions during my stay in the village. This method of data collection consisted of going into the mangroves or some other area of the village, or going out to sea on a fishing boat with an informant, listening to him and asking him about the surroundings. Field interviews allow informants to talk more about their perception of nature around them and their livelihood. The information was noted down during fieldwalking ${ }^{3}$ (walking or going in the areas). Real objects, pictures and photographs taken during data collection were used as complementary aids during the interviews.

I collected as many key words or specific terms as possible (all the different landforms, water phenomena, waves, for example) learned from direct questioning and from discourse data and asked about each word's specific meaning in detail. For analysis, the lexical items were classified into subsets (subfields) according to paradigmatic sense-relations. Later, an ethnosemantic approach ${ }^{4}$ was applied for analysis of the lexical items. A

${ }^{3}$ The term 'fieldwalking' is used in the elicitation guide of Bohnemeyer et al. (2004: 76).

${ }^{4}$ Ethnosemantics or ethnographic semantics is viewed as a part of cognitive anthropology (Levinson and Ember, 1996: 209), studying the way in which different cultures organize and categorize domains of knowledge, such as plants, animals, and kin and how meaning is structured in different cultural settings in order to understand the cognitive system of any 
folk taxonomy of 'kind of' relationships within each category and the componential meaning of words are identified in the analysis.

\section{Terms and classification of landscape}

This section reveals how the Thai coastdwellers of Bang Khunsai perceive and categorize the landscape in which they live through their terminology, including terms for sea, soil, water, and forest, respectively. Terms will be listed along with their cultural meanings and identified in relation to their typical way of classification.

\section{Sea type and related geographical localities}

Sea with mudflats, such as that found in Bang Khunsai Subdistrict, or with a foreshore area consisting of a mixture of mud and sand, is locally regarded as a $/ \mathrm{t}^{\mathrm{h}}$ ale:tî: $\mathrm{n} /$ (ทะเลตื้น) 'shallow sea' type which is different from / $\mathrm{t}^{\mathrm{h}}$ ale:lík/ (ทะเลลึก) 'deep sea'. Folk classification of the sea can be shown in the following hierarchy.

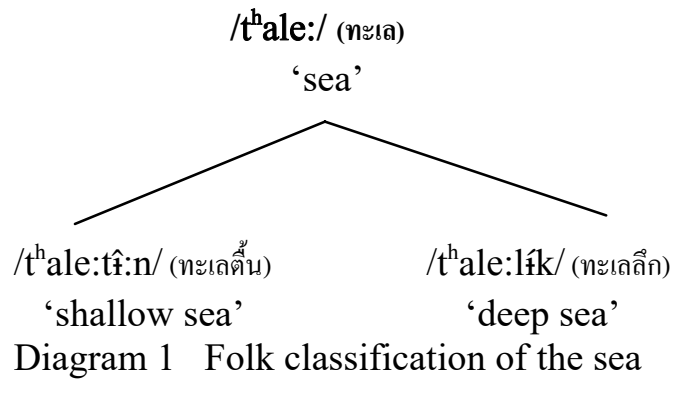

group. So, studies using this approach are interdisciplinary, involving linguistics and anthropology. The ethnosemantic approach and its concepts are made clear in the article, "The Ethnographic Study of Cognitive Systems" by Frake (1962), one of the pioneers of ethnosemantic studies.
The term / $\mathrm{t}^{\mathrm{h}}$ ale:tî:n/ (ทะเลตื้น) 'shallow sea' refers to the sea with a large foreshore area. Towards the sea, the foreshore maintains the same level before gradually sinking. When the water is low, a large flat emerges out of the sea. According to the locals, generally, $/ \mathrm{t}^{\mathrm{h}}$ ale:tî̀:n/ (ทะเลตื้น) has softer and smaller waves, compared with the other type. The closer it is to the shore, the softer the waves. In areas of this sea type, fishing activities can take place not far from the foreshore, known as coastal fishing. On the other hand, / $\mathrm{t}^{\mathrm{h}}$ ale:lík/ (ทะเล ลึก) 'deep sea' refers to sea with a narrow foreshore area. When the water is low, a plot of sand emerges not far from the shore. Offshore, the land sinks away forming a pan-like shape resembling an inland basin. In most cases, sea with a beach is classified as this type. Fishing activities are possible in the deeper areas away from the shore.

It can be summarized that the dimension of semantic contrast between different types of sea according to the locals' perspective is physical features and benefits, namely, the width of foreshore area at the time the tide is receding, the slope of the foreshore, the nature of the foreshore area, the strength of the waves, and also type of fishery related to the sea as expressed below ${ }^{5}$ :

\footnotetext{
5 The semantic or componential feature is marked with a sign $[+]$ for the positive value, $[-]$ for the negative value, and a sign $[+]$ for value of the variable which have both positive and negative values.
} 


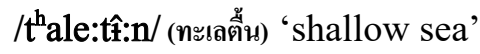

+ wider foreshore area

+ foreshore sinking into the sea

+ foreshore area being mudflat

- stronger waves

+ coastal fishing

Geographical localities and landforms which dominate the landscape are identified by terms such as / $\mathrm{c}^{\mathrm{h}} \mathrm{a}$ :yfây/ (ชายฟั่ง) 'coast', / $\mathrm{c}^{\mathrm{h}} \mathrm{a}: \mathrm{yt}^{\mathrm{h}}$ ale:/ (ชายทะเล) 'seaside', /hǔapà:/ (หัวป่า) 'beginning - forest (the point where fishing boats travel in or out to sea; noticeably, tall trees grow densely

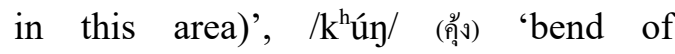
watercourse', /lě:m/ (แหลม) 'cape', /kò?/ (เกาะ) 'island or dune above water', and /Rà:w/ (อ่าว) 'bay, gulf'. Another word, /hà:t/ (หาด) 'beach' is mentioned as well. The locals' concept of this word is that of an area spanning the length and breadth of the shore, and firm enough to be walked on. The term does not only refer to sand beach. As the locals reported, in the past, the shore in Bang Khunsai Subdistrict was /hà:t/ (หาด) made up of fragments of shells, locally called /hà:t krasá:/ (หาดกระซ้า) 'Kraza beach'. In the locals' view, it was more beautiful than conventional beaches. It was possible to walk on without fear of getting stuck in mud. However, the site no longer exists. As the shore area being muddy, it is not locally called /hà:t/ (หาด) at all because it is impossible to walk on. /thale:lł́k/ (ทะเลลึก) 'deep sea'

- wider foreshore area

- foreshore sinking into the sea

- foreshore area being mudflat

+ stronger waves

- coastal fishing

\section{Terms for soil}

Local soils are classified into different types, divided into two groups based on area or zone where the soil is found; one soil group in the sea or other water source, and the other on land. Folk classification of local soils and terms are illustrated in the taxonomic hierarchy in Diagram 2. 
/din/ (ดิน)

'soil, ground'

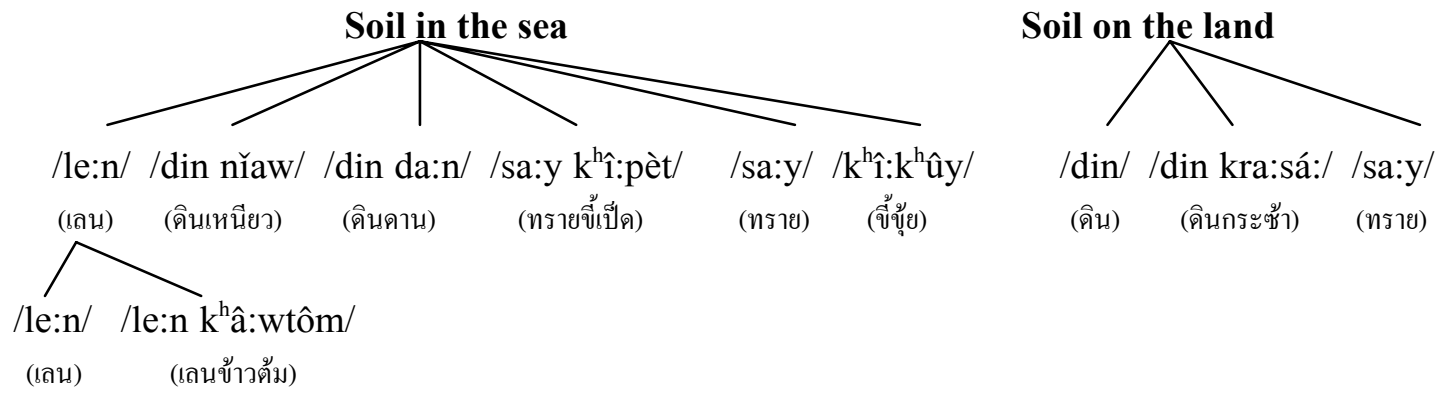

Diagram 2 Folk classification of local soils

The category of mire called /le:n/ (เลน) referring to wet, muddy soil along the coastal areas is of particular interest. This type of soil is specifically identified based on its physical features: /le:n khâ:wtôm/ (เลนข้าวต้ม) 'porridge-like mire', /le:n ?ò:n/ (เลนอ่อน) 'soft mire' and /le:n yà:p/ (เลนหยาบ) 'rough mire' (see Figure 3). Of these three terms, /le:n k k̂a:wtôm/ (เลนข้าวต้ม) is distinctly classified into a type of /le:n/ (เลน). It refers to a very muddy soil resembling porridge with half of its elements consisting of water, and as such is thus labeled /le:n khâ:wtôm/ (เลนข้าวต้ม), literally, 'porridge-mire'. Another, /le:n ใว̀:n/ (เลนอ่อน), refers to wet, muddy soil but with a more soil-like texture than /le:n $\mathrm{k}^{\mathrm{h}}$ â:wtôm/ (เลนข้าวต้ม). Compared to /le:n yà:p/ (เลนหยาบ), /le:n 1ว̀:n/ (เลนอ่อน) is less compact.

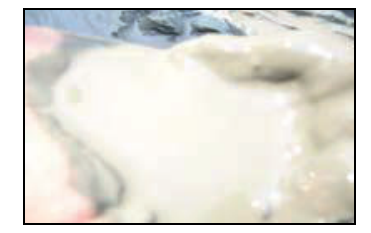

/le:n k â:wtôm/ (เลนข้าวต้ม)

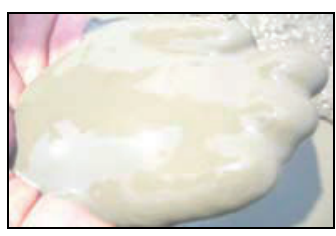

/le:n ใว̀:n/ (เลนอ่อน)

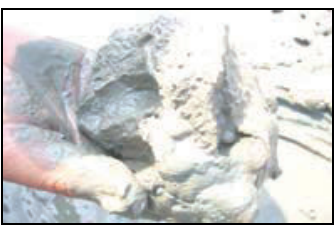

/le:n yà:p/ (เลนหยาบ)

Figure 3 /le:n khâ:wtôm/ (เลนข้าวต้ม), /le:n ใò:n/ (เลนอ่อน), and /le:n yà:p/ (เลนหยาบ) 
According to the locals' experience, /le:n $\mathrm{k}^{\mathrm{h}} \mathrm{a}: w t o ̂ m /$ (เลนข้าวต้ม) is exclusively present in particular parts of the sea area in Bang Khunsai Subdistrict. Species such as blood cockle grow well in this soil and are tasty when cooked. However, in an area where the mire is thick /le:n k $\mathrm{k}^{\mathrm{h}} \mathrm{a}: \mathrm{w}$ tôm/ (เลนข้าวต้ม), mud-skiing is difficult.

Another sea-soil term is /din nǐaw/ (ดินเหนียว) 'clay' which refers to a wet, muddy soil along the shore or at the river bank where flooding is temporary. A subsoil with hard and compact features found along the sea bed or other water source is called/din da:n/ (ดินดาน). According to the locals, this type of subsoil is found 12 inches or more below the surface. Other types are /sa:y/ (ทราย) 'sand' and /sa:y k 1̂̀:pèt/ (ทรายขี้เป็ด), literally, 'sand-duck excrement'. /sa:y/ (ทราย) refers to very small grains of rock. /sa:y khî:pèt/ (ทรายขี้เป็ด) refers to the mushy soil consisting of sand and fragments of shells mixed with mire. This term is so coined because it looks disgusting, resembling the excrement of a duck. In addition, the soil around the burrow of a sea creature (e.g. that of crabs, fish and some shellfish) is identified and specifically named $/ \mathrm{k}^{\mathrm{h}} \hat{\mathrm{l}}: \mathrm{k}^{\mathrm{h}}$ ûy/ (ขี้ขุ้ย), literally, 'excrement-Khui'. The word / $\mathrm{k}^{\mathrm{h}} \mathrm{ûy} /$ (ขุ้ย) in the term $/ \mathrm{k}^{\mathrm{h}} \hat{\mathrm{i}}: \mathrm{k}^{\mathrm{h}} \mathrm{ûy} /$ (ขี้ขุ้ย) is not found to be significant.

The majority of the soil on the coastal land of Bang Khunsai is made up of a type locally known as /din kra:sá:/(ดินกระซ้า). The term refers to a mixture made up of shell fragments (crushed dead shellfish) called /kra:sá:/ (กระซ้า) with soil. Along the coast where tidal movement delivers seashells and mire which mix together to form dry land, is /din kra:sá:/ (ดินกระซ้า). The locals commonly use this soil for landfill because of its properties - it is stable and doesn't turn muddy in rain or flood. Another different type is /sa:y/ (ทราย) 'sand'. Apart from that, the coastal locals rarely classify different types of soil on the land. Therefore, the general term/din/ (ดิน) 'soil, ground' is used.

The coastal villagers characterize local soil based on a variety of dimensions. They mainly pay attention to physical features or properties and texture (determined by the number of component particles). Table 1 shows the significant semantic features presented in the dimensions of contrast of terms for soils according to villagers which are: softness (muddy - hard); stickiness (sticky - unsticky); shaping ability (able to make shapes - unable to make shapes); stability (stable-unstable); and source (in water or on land), as well as suitability for mud-skiing. 
Table 1 The semantic dimensions of contrast of terms for soil

\begin{tabular}{|c|c|c|c|c|c|c|c|c|c|c|c|}
\hline Semantic features & 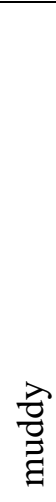 & 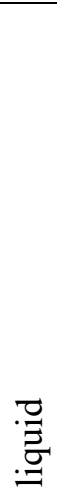 & $\frac{\vec{y}}{\stackrel{\theta}{\theta}}$ & 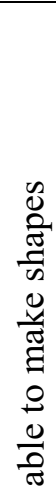 & 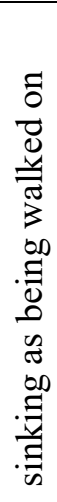 & 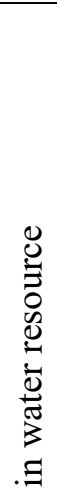 & 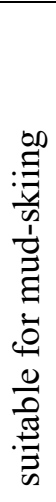 & 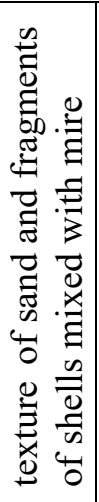 & 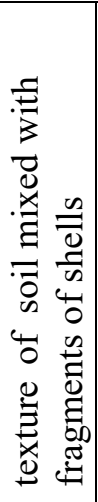 & 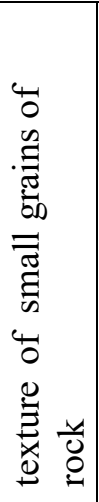 & 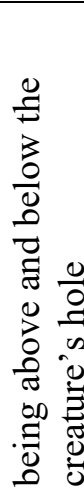 \\
\hline /le:n/ (เลน) & + & - & - & - & + & + & + & & & & \\
\hline $\begin{array}{l}\text { /le:n khâ:wtôm/ } \\
\text { (เลนข้าวต้ม) }\end{array}$ & + & + & - & - & + & + & - & & & & \\
\hline /le:n 1ว̀:n/ (เลนอ่อน) & + & - & - & - & + & + & + & & & & \\
\hline /le:n yà:p/ (เลนหยาบ) & + & - & 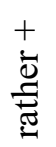 & 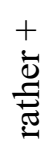 & + & + & + & & & & \\
\hline /din/ (ดิน) & - & - & - & - & - & - & - & & & & \\
\hline /din nǐaw/ (ดินเหนียว) & - & - & + & + & - & + & - & & & & \\
\hline /dinda:n/ (ดินดาน) & - & - & $\begin{array}{l}+ \\
\stackrel{D}{D}\end{array}$ & + & - & + & - & & & & \\
\hline /din kra:sá:/ (ดินกระซ้า) & - & - & - & - & - & - & - & & + & & \\
\hline /sa:y/ (ทราย) & - & - & - & - & - & \pm & - & & & + & \\
\hline /sa:y kĥ̂:pèt/ (ทรายขี้เป็ด) & - & - & - & - & - & + & - & + & & & \\
\hline$/ \mathrm{k}^{\mathrm{h}} \hat{1}: \mathrm{k}^{\mathrm{h}} \mathrm{ûy} /$ (ขี้ขุ้ย) & + & - & - & - & + & + & - & & & & + \\
\hline & \multicolumn{7}{|c|}{ Binary features 6} & \multicolumn{4}{|c|}{ Unique features } \\
\hline
\end{tabular}

${ }^{6}$ With respect to semantic dimensions, the binary features were adapted to justify positive or negative values for soil terms. Although there seem to be continuum of degree of the positive value, (e.g. "very+"), and it could be the feature that differentiates /dinda:n/(ดินตาน) 'subsoil' from /din nǐaw/ (ดินเหนียว) 'clay', such contrast with intervening feature is found only in the meaning of /dinda:n/ (ดินดาน). For these reasons, we might not be able to assume the continuum is the main feature that systematically differentiates the meaning of the terms in this word set. Nevertheless, if in the future someone conducts a similar research and find similar patterns of differentiation, we may regard semantic dimensions of the contrast to be continua. This area is, therefore, open for further studies. 
Besides identification of soil type, the coastal locals also classify the burrows or /ru:/ (รู) of marine creatures found above and below the soil surface. The terms for such types of burrows include /ru:lon/ (รูลง) 'downward hole', /ru:kĥ̀̂n/ (รูขึ้น) 'upward hole', /ru:dìy/ (รูดึ่ง) 'straight hole', and /ru: $\mathrm{c}^{\mathrm{h}} \mathrm{\rho}: \mathrm{n} /$ (รูชอน) 'meandering hole'. Some terms are used analogically with something else familiar to villagers. For example, the term /ru:mô:/ (รูหม้อ) meaning 'pot hole' derives from its shape which is round and looks like a pot; the term /ru:tâu/ (รูเต้า) is used because the middle of the hole is dimpled, resembling part of a Thai sweet cooking pan called "Tao Kha Nom Krok" (เต้าขนมครก); and the term /ru:làk/ (รูหลัก) refers to the wedge shell's hole which is a hollow channel into the soil like a pole or stake. The coastal area of Bang Khunsai consists mainly of mire. When one takes a walk along the coast, part of their leg is likely to sink deep into it. The more one tries to walk close to a sea creatures burrow, the more easily their legs will sink deep into it, possibly up to thigh level.

\section{Water terms in landscape}

Those who have been living in coastal areas expertly observe the changing sea tides to determine when best to go out to sea. The terms coined for such natural water phenomena clearly describe the main characteristics of seawater at that time. Water fluctuations in terms of level or quantity are referred to by such terms as /ná:m khân/ (น้ำขึ้น) 'high tide' which directly contrasts with /ná:m loy/ (น้ำลง) 'low tide'; /ná:m kò:t/ (น้ำเกิด) or /ná:m pen/ (น้ำเป็น) 'spring tide' which is opposite to /ná:m ta:y/ (น้ำตาย) 'neap tide'. Also used are mutually related pairs of terms such as /ná:m thă:/ (น้ำเท้อ) and /ná:m t $\mathrm{t}^{\mathrm{h}} \mathrm{a}: \mathrm{m} /$ (น้ำทาม), ${ }^{7}$ and /ná:m lót/ (น้ำลด) 'water-recede' and /ná:m $\mathrm{t}^{\mathrm{h}} \mathrm{s}: \mathrm{n} /$ (น้ำทอน) 'water-retreat'. There are many terms which indicate water condition: /ná:m bìat - ná:m $\mathrm{kan} /$ (น้ำเบียด-น้ำ กัน), literally, 'water-bump (or 'red tides' in scientific terms)'; /ná:m nǔn/ (น้ำหนุน) 'water-to pile up (there by creating a tidal bore)'; /ná:m k $\mathrm{k}^{\mathrm{h}}$ wă:y/ (น้ำขวาง) 'watervertical'; /ná:m pát/ (น้ำปัด) 'water changing in direct'; /ná:m won/ (น้ำวน) 'whirlpool'; and /phra:y ná:m/ (พรายน้ำ) 'phosphorescent' etc. (see Kamnuansin 2012 for details). Moreover, subfields of terms for water season, water cycle, and waves can be particularly categorized as shown below. The ability of coastal locals to precisely discern water seasons and cycles is considered in-depth knowledge specific to this area and not common among people in other areas.

\subsection{Water season}

Everyday utterances such as, "/c châan ní: pen nâ: ná:m kla:ywan/” (ช่วงนี้เป็นหน้าน้ำ กลางวัน) 'This period is a daytime water season' or "//kâw ná:m kla:yk hì

\footnotetext{
${ }^{7}$ The term /ná:m thå:/ (น้ำเท้อ) locally refers to the water condition when its level is high as the water is receding. The water level then alternates repeatedly, (almost hesitatingly), from low to high. /ná:m $\mathrm{t}^{\mathrm{h}} \mathrm{a}: \mathrm{m} /$ (น้ำทาม) refers to the water level when it does not recede beyond a particular point from the shore and the current is slow. Generally, these two states occur at the same time, usually during neap tide.
} 
(เข้าน้ำกลางคืนแล้ว) 'It is nighttime water season now', indicate that the coastal villagers in Bang Khunsai pay great attention to the sea and consider phenomena related to the sea as regular seasons. The state of the seawater is locally classified according to two annual seasons based on the time each day that corresponds to the tidal pattern; one is called /nâ: ná:m kla:Đwan/ (หน้าน้ำ กลางวัน) 'daytime water season' and the other is called /nâ: ná:m kla: $\mathrm{jk}^{\mathrm{h}} \mathrm{i}: \mathrm{n} /$ (หน้าน้ำ กลางคืน) 'nighttime water season', divided approximately in half into six-month periods. The interval between these two water seasons is referred to as the period of /ná:m c $\mathrm{c}^{\mathrm{h}}$ aylaw/ 'Chailaw water' (น้ำไชเลา) as illustrated in Figure 4.

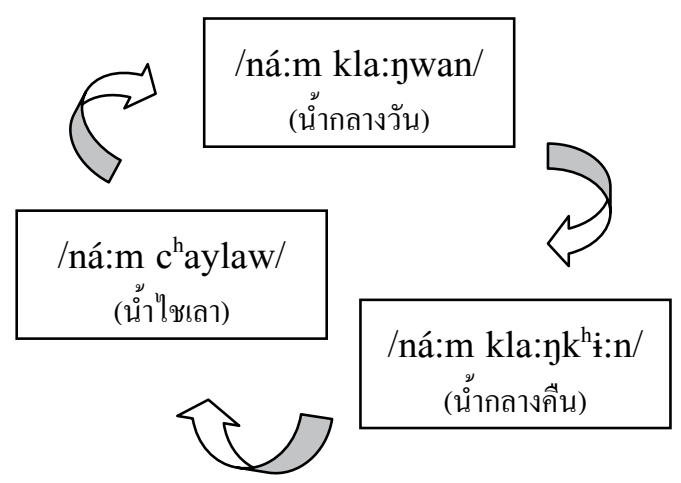

Figure 4 The annual cycle of the water season

The seawater on days when it ebbs away from the shoreline to the point that the mudflats are exposed during the day (between dawn to 1 p.m.) is referred to by the term /ná:m kla:ywan/ (น้ำกลางวัน) 'waterdaytime'. The period known as /nâ: ná:m kla:ywan/ (หน้าน้ำกลางวัน) 'daytime water season' is from February to July. The term /ná:m kla:yk $k^{\mathrm{h}} \mathrm{i}: \mathrm{n} /$ (น้ำกลางคืน) 'water- nighttime' refers to the seawater on days during which it ebbs away from the shoreline to the point that the mudflats are exposed during the night (between 7 p.m. to 2 or 3 a.m.). The corresponding period of /nâ: ná:m kla:yk $\mathrm{k}^{\mathrm{h}} \mathrm{i}: \mathrm{n} /$ (หน้าน้ำกลางคืน) 'nighttime water season' occurs from August to January. Daytime seawater that recedes from the shoreline until mudflats are exposed in the late afternoon or evening (between 2 p.m. to dusk) is referred to by the term /ná:m $\mathrm{c}^{\mathrm{h}}$ aylaw/ (น้ำไช เลา) 'water-Chailaw'. This period occurs from January to the beginning of April and is the transition period between the season of /ná:m kla:yk $\mathrm{k}_{\mathfrak{h}}^{\mathrm{i}}: \mathrm{n} /$ (น้ำกลางคืน) and /ná:m kla:ywan/ (น้ำกลางวัน). /ná:m $\mathrm{c}^{\mathrm{h}}$ aylaw/ (น้ำไชเลา) is also known as /hǔa ná:m kla:ywan/(หัวน้ำ กลางวัน) 'begining of daytime water'.

Water seasons influence the fishing activities of the communities, especially the use of mud-skiing to catch cockles. In the season of /ná:m kla:ywan/ (น้ำกลางวัน), the locals usually go out to fish during the daytime. They conduct their fishing activities at sea during the night during the season of /ná:m kla:yk $\mathrm{k}^{\mathrm{h}} \mathrm{i}: \mathrm{n} /$ (น้ำกลางคืน). During the state of /ná:m $\mathrm{c}^{\mathrm{h}}$ aylaw/ (น้ำไชเล), they mostly go fishing in the late afternoon or evening.

Apart from these, there are other water terms recognized by locals that refer to the seawater at particular times related to the

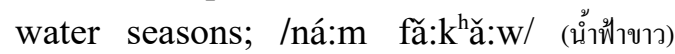
'water-white sky', specifically, refers to the water at the time it rises around 4 a.m. to 6 a.m. before sunrise (the word /fã:kă:w/ (ฟ้าขาว) 'white sky' describes the time before dawn). This occurs during November and December during the 
season of /ná:m kla: $\mathrm{kk}^{\mathrm{h}} \mathfrak{\mathrm { i }}: \mathrm{n} /$ (น้ำกลางคืน). Those who wish to catch sergestid shrimps have to leave early to make their catch at that time. However, in general terms, the word /ná:m fă:kă:w/ (น้ำฟ้าขาว) means the water daily at dawn, regardless of it being high or low tide.; /ná:m fă:dam/ (น้ำฟ้าดำ) 'water-black sky', specifically, refers to water at the time it recedes, around 6 p.m. to 7 p.m. (the word /fã:dam/ (ฟ้าดำ) 'black sky' describes the time when it is almost dusk). It occurs in December, January, and February in the period of /ná:m $\mathrm{c}^{\mathrm{h}}$ aylaw/ (น้ำไชเลา), about 2-3 days in one water period like /ná:m fã:kȟ̆:w/ (น้ำฟ้าขาว). In general terms, the word /ná:m fă:dam/ (น้ำฟ้าดำ) means the water at dusk which occurs daily. And the term /ná:m phá? k kº́? $\mathrm{rak}^{\mathrm{h}} \mathrm{ay} /$ (น้ำพระเคาะระฆัง), literally, 'watermonk-toll-bell', refers to water as it rises again after receding from the shoreline, or water receding from the shoreline between 4 and 5 a.m. Coincidentally, this is the time when Buddhist monks toll the temple bell. The moment occurs a few times in the season of /ná:m kla: $\mathrm{kk}^{\mathrm{h}} \mathrm{i}: \mathrm{n} /$ (น้ำกลางคืน) between the middle of August to November, around the time of Buddhist Lent. The term was coined in relation to a specific social time. Fisherfolk go out to fish around 10 p.m. and return home just before dawn, around 4 a.m. When the bell is heard, they know the time and that the tide is rising. What is more, in August, before /ná:m kla:ywan/ (น้ำกลางวัน) is over, /ná:m $\mathrm{p}^{\mathrm{h}} \mathrm{rá}$ ? $\mathrm{k}^{\mathrm{h}}$ ? $\mathrm{rak}^{\mathrm{h}} \mathrm{ay} /$ (น้ำพระเคาะระฆัง) is the water receding between 4 and 5 a.m. Hearing the sound of the bell, the villagers prepare to go out fishing.

\subsection{Water cycle}

By observing and recognizing the naturally receding water from the foreshore area, the coastal locals realize that seawater changes are cyclical based on the date as reckoned by lunar movements. A cycle of water is locally referred to by the term /nìn ná:m/ (หนึ่งน้ำ) 'one-water'. It takes around 15 days to complete as shown in Figure 5.

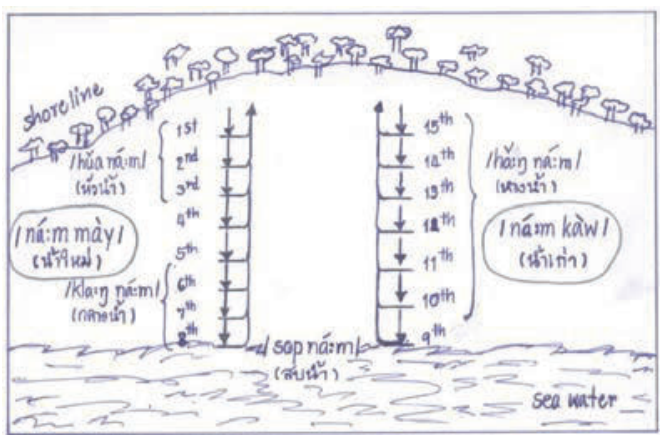

$\downarrow$ shows level of the water recession

Figure 5 depicts the level of water recession over 15 days for one water cycle counted as /nìn ná:m/ (หนึ่งน้ำ) 'one-water'

The term /nìn ná:m/ (หนึ่งน้ำ) 'one-water' refers to a water cycle counted from when its level begins to recede and dry up to about a 30 wa (60 meters) distance from the shoreline. The rate of seawater recession increases over the next days until the day when the water returns to recede to a point equidistant from the shoreline as at the beginning of the first day of the receding seawater (see Figure 5 above). Over the next 15 days, water recession repeats as before, counting another water cycle. The locals then divide the month into two water cycles, called /sǒ:y ná:m/ (สองน้ำ) 'two-water'. The cycle continues like this every month. Relevant 
terms for periods in one 15-day water cycle are illustrated in Figure 6.

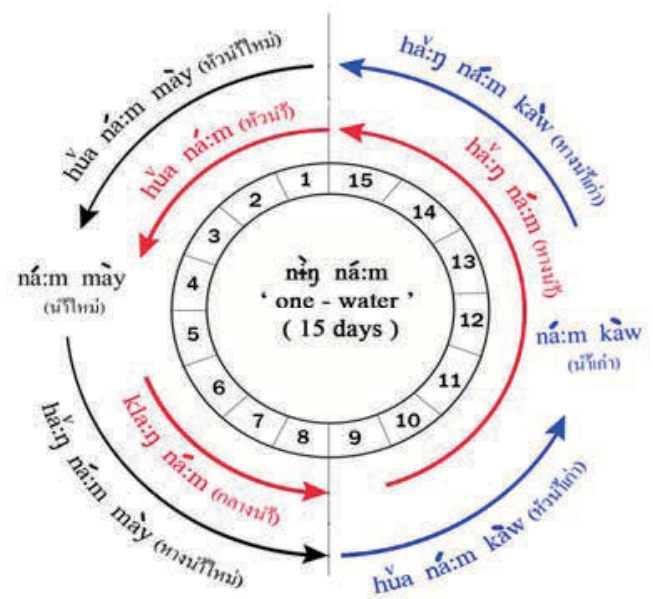

Figure 6 Relevant terms for periods during one water cycle

In one water cycle or /nìn ná:m/ (หนึ่งน้ำ), there is a division into different stages of water recession based on date. The continuation of each period is represented by the set of part terms: /hǔa/ (หัว) 'beginning', /kla:y/ (กลาง) 'middle' , and /hă:y/ (หาง) 'last'.

The water at the stage when it recedes away from the shoreline during its first 3 days is referred to by the term /hǔa ná:m/ (หัวน้ำ) 'beginning-water'. According to the locals, the seawater recedes no more than 120 wa (240 meters) from the shoreline during this stage. A minimal area of foreshore emerges out of the sea, so collecting shellfish during this period is not popular. The stage when water has receded during the $6^{\text {th }}, 7^{\text {th }}$, and $8^{\text {th }}$ days, from the first day of the water receding or /hǔa ná:m/ (หัวน้ำ), is called by the term /kla:y ná:m/ (กลางน้ำ) 'middle-water'. In this state, the seawater is very far from the shoreline. Collecting shellfish during this stage is usually possible for many hours because the dry foreshore is vast and shellfish abundant. Finally, the term /hă:y ná:m/ (หางน้ำ), 'last-water' refers to water in the state when it recedes away from the shoreline during the $9^{\text {th }}, 10^{\text {th }}, 11^{\text {th }}, 12^{\text {th }}$, $13^{\text {th }}, 14^{\text {th }}$, and $15^{\text {th }}$ days, from the first day of the water receding cycle. During this stage, the seawater recedes far from the shoreline to the same point as the /hǔa ná:m/ (หัวน้ำ) stage. The water level is not high, a state referred to as /ná:m ta:y/ (น้ำ ตาย), and the collection of shellfish during this stage is not popular because the exposed foreshore is not so vast and most shellfish have likely already been collected in the days prior.

The period from the first day of /hǔa ná:m/ (หัวน้ำ) to the last day of /hă:y ná:m/ หางน้ำ, is counted as one full water period called /tem ná:m/ (เต็มน้ำ) 'full-water'. Half of a /nìn ná:m/ (หนึ่งน้ำ) 'one water', taking 7-8 days, goes from the period of /hǔa ná:m/ (หัวน้ำ) to /kla:y ná:m/ (กลางน้ำ) or from /kla:y ná:m/ (กลางน้ำ) to /hă:y ná:m/ (หางน้ำ), and is counted as the half water period called /khrîn ná:m/ (ครึ่งน้ำ) 'half-water'. The transition of water from one period to another, as recognized by the villagers, is identified by these terms, /ná:m mày/ (น้ำ ใหม่) 'new water' and /ná:m kàw/ (น้ำเก่า) 'old water'. The terms reflect the condition of newness and oldness of the water based on whether the water occurs at the beginning of the period or in the period exploited by the villagers or thereafter. 
The water in the beginning period or the state of /hǔa ná:m/ (หัวน้ำ) is called /ná:m mày/ (น้ำใหม่) 'new water'. This term applies until the water reaches the state of /kla:y ná:m/ (กลางน้ำ). The beginning of the period of /ná:m mày/ (น้ำใหม่) is called /hûa ná:m mày/ (หัวน้ำใหม่). The term /ná:m kàw/ (น้ำเก่า) 'old water' refers to water after the period of /kla:y ná:m/ (กลางน้ำ) and beyond, which is in the period of /hă:n ná:m/ (หางน้ำ). It is also used to define the previous water period that has just ended. During the period of /ná:m kàw/ (น้ำเก่า), the majority of villagers do not go out to sea to fish because previous fishing activities have already reduced the potential size of the catch.

\subsection{Waves}

Two common types of sea wave, /dà:y/ (เดิ่ง) and $/ \mathrm{k}^{\mathrm{h}} 1 \hat{\mathrm{x}}: \mathrm{n} /$ (คลื่น), are classified based on their characteristics as shown in the diagram below. These are further referenced by specific terms such as $/ \mathrm{k}^{\mathrm{h}} 1 \hat{\mathrm{x}}: \mathrm{n}$ yà:p/ (คลื่นหยาบ) and / $\mathrm{k}^{\mathrm{h}} 1 \hat{\mathrm{y}}: \mathrm{n}$ hǔafǒn/ (คลื่นหัวฝน).

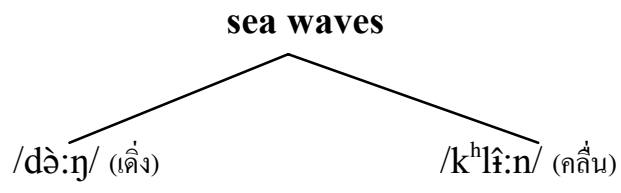

Diagram 3 folk classifications of sea waves

A wave with its head unbroken is referred to by the term /dò:y/ (เดิ่ง). This means that the crest of the wave retains its form, without breaking into bubbles as it moves. According to the locals, the interval between waves is quite long, so one /dò:y/
(เดิ่ง) may follow another at a maximum distance of 2-3 wa (4-6 meters). /də̀:y/ (เดิ่ง) come constantly and run evenly, parallel to the shore for a considerable distance. Local villagers have noticed that when riding the /dà:y/ (เดิ่ง) by boat, they can feel the boat moving up and down as if they were traveling by bus into the hills. They believe that /dà: $\mathrm{y} /$ (เดิ่ง) is an underwater wave because its size and force do not depend on the wind. /dò:y/ (เดิ่ง) come in different sizes, big and small. In deep sea, /də̀:y/ (เดิ่ง) is often big, whereas in shallow sea, it is rather small. This kind of wave is dangerous if it is big and likely to cause small fishing boats to capsize. The villagers have noticed that prior to a strong wind, /d̀̀:y/ (เดิ่ง) is evident first, followed by the wind and other waves. This signifies that there might be an approaching storm.

Another, $/ \mathrm{k}^{\mathrm{h}} 1 \hat{\mathrm{x}} \mathrm{n} / \mathrm{n}$ (คลื่น), refers to a wave with its head broken, in other words, where the crest has burst into bubbles. $/ \mathrm{k}^{\mathrm{h}} \mid \hat{\mathrm{x}}: \mathrm{n} /$ (คลื่น) waves are irregular and arrive at shorter intervals compared to /dò:y/ (เดิ่ง). Each is closely followed by another. Chop is, small waves without a broken head but with the previously mentioned characteristics, also called $/ \mathrm{k}^{\mathrm{h}} 1 \hat{\mathrm{r}}: \mathrm{n} /$ (คลื่น). $/ \mathrm{k}^{\mathrm{h}} \mid \hat{\mathrm{r}}: \mathrm{n} /$ (คลื่น) is bumpy, unlike /dò:y/ (เดิ่ง) which has a long horizontal pattern (see Figure 7). Some locals describe a boat riding the top of a $/ \mathrm{k}^{\mathrm{h}} 1 \hat{\mathrm{n}}: \mathrm{n} /$ (คลื่น), as like being in a car as it goes over bumps and potholes. Normally, $/ \mathrm{k}^{\mathrm{h}} \mathrm{l} \hat{\mathrm{n}} \mathrm{n} / \mathrm{n}$ (คลื่น) roll in from out to sea and sometimes, they also move from the shore towards the open sea if the wind blows in that direction. The more powerful the wind, the bigger the 
$/ \mathrm{k}^{\mathrm{h}} \mathrm{l} \hat{\mathrm{x}}: \mathrm{n} /$ (คลื่น). A big or rather big $/ \mathrm{k}^{\mathrm{h}} \hat{\mathrm{r}}: \mathrm{n} /$ (คลื่น) is specifically called $/ \mathrm{k}^{\mathrm{h}} 1 \hat{\mathrm{t}}: \mathrm{n}$ yà:p/ (คลื่น หยาบ) 'non-fine wave'. The majority of $/ \mathrm{k}^{\mathrm{h}}$ l̂̀:n yà:p/ (คลื่นหยาบ) have a bubble crest. The closer they get to the shallows, the more they break into white bubbles if the wind is strong enough. Another term for wave is $/ \mathrm{k}^{\mathrm{h}} 1 \hat{\mathrm{r}}: \mathrm{n}$ hǔafǒn/ (คลื่นหัวฝน), 'wavebeginning the rain' referring to waves that emerge before rain, usually accompanied by wind shortly after.

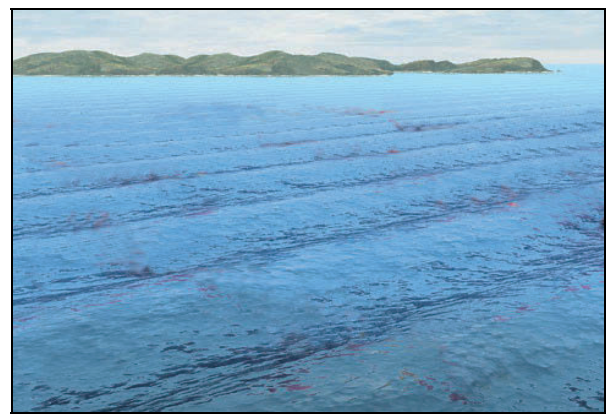

/dò:y/ (เดิ่ง)
The size of the waves depends on how strong the wind is. Generally, $/ \mathrm{k}^{\mathrm{h}} \mathrm{l} \hat{\mathrm{r}}: \mathrm{n}$ hǔafǒn/ (คลื่นหัวฝน) are huge and may be referred to as $/ \mathrm{k}^{\mathrm{h}} 1 \hat{\mathrm{x}}: \mathrm{n}$ yà: $\mathrm{p} /$ (คลื่นหยาบ). According to the locals, these waves are powerful and frequent because the wind prior to rain is usually strong.

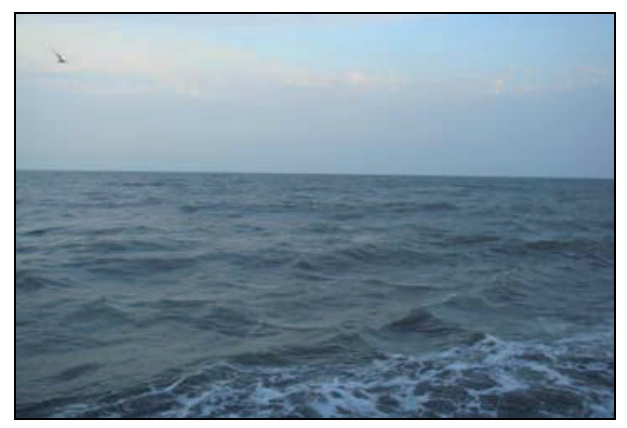

$/ \mathrm{k}^{\mathrm{h}} 1 \hat{\mathrm{l}}: \mathrm{n} /$ (คลื่น)

Figure $7 / \mathrm{d} \partial े: \mathrm{y} /$ (เดิ่ง) on the upper and $/ \mathrm{k}^{\mathrm{h}} 1 \mathrm{l} \hat{\mathrm{x}} \mathrm{n} /$ (คลื่น) on the lower

From the folk definitions of terms, there are three significant semantic features used to contrast /dò:n/ (เดิ่ง) from $/ \mathrm{k}^{\mathrm{h}} \mathrm{l} \hat{\mathrm{n}}: \mathrm{n} /$ (คลื่น): the patterns of the wave crest (broken crest -

/dò:y/ (เดิ่ง)

- broken crest

+ long interval between waves

+ consistent wave shape unbroken crest), the intervals between waves (long-short), and wave shape (consistent - inconsistent) as summarized below. 
Villagers notice similarities between /dò:y/ (เดิ่ง) and $/ \mathrm{k}^{\mathrm{h}} 1 \hat{\mathrm{r}}: \mathrm{n} /$ (คลื่น) in that, when they move from sea to steep shore or high land, the steeper the shore, the stronger the waves are. They break strongly against the shore generating a foam of white bubbles. And if /dà: $\mathrm{y} /$ (เดิ่ง) and $/ \mathrm{k}^{\mathrm{h}} 1 \hat{\mathrm{n}}: \mathrm{n} /$ (คลื่น) are big enough and crash onto a steep incline, the waves might loop back again after hitting, whereas if they strike plain shore, they tend to break and recede with their force diminishing.

Knowledge of the characteristics of waves helps the villagers avoid danger while out fishing at sea. They are able to forecast storms or rain by observing the waves. They have also learned to steer their boats safely in rough seas by not aligning the boat horizontally to the waves, and zigzagging instead to prevent the boat from capsizing. Knowing the direction of waves known as /də̀:y/ (เดิ่ง) also helps them determine where to point the boat towards shore.

\section{Terms for mangrove forest}

Any area where various mangrove trees grow in large numbers over a rather wide expanse of land is locally referred to as /pà:/ (ป่า) 'forest'. Types of mangrove forests are identified by the dominant kind of trees growing in that particular area. For example, an area where there are /samě:/ (แสม) 'trees of the genus Avicennia' is called /pà:samě:/ (ป่าแสม) 'Samae forest'. A majority of /ko:yka:y/ (โกงกาง) 'trees of the genus Rhizophora or mangrove tree' identifies a /pà:ko:yka:y/ (ป่าโกงกาง) 'Kongkang forest'. /pà:tabu:n/ (ป่าตะบูน) 'Tabun forest' is where/tabu:n/ (ตะบูน) 'trees of the genus Xylocarpus' are most abundant. However, the name, /pà: $\mathrm{c}^{\mathrm{h}} \mathrm{a}: \mathrm{yle}: \mathrm{n} /$ (ป่าชาย เลน), literally 'forest-wetlands', is a general term for forests close to coastal areas, regardless of what tree species is growing there. ${ }^{8}$ The villagers claim that the term is an official one.

From the locals' perspective, /pà:samě:/ (ป่า แสม) is of natural origin. It is not necessary to plant /samع̌:/ (แสม) trees because they grow naturally. In nature, /samě:/ (แสม) seeds are able to float along with the current before reaching suitable land and germinating. Meanwhile, /pà:ko:yka:y/ (ป่า โกงกาง) is artificially grown in many areas because /ko:yka:y/ (โกงกาง) trees do not reproduce as easily as /samě:/ (แสม) trees. /ko:yka:y/ (โกงกาง) pods, which fall and sink into the mud around the trees, are able to germinate but if the pods are removed to coastal areas for planting, it is likely that they will be washed away by the sea tide. This highlights the semantic features of terms used by locals to contrast these two types of forests as depicted below.

/pà:samě:/ (ป่าแสม)

+/samě:/ trees as its majority

+ natural forest

/pà:ko:yka:y/ (ป่าโกงกาง)

+/ko:yka:y/ trees as its majority

\pm natural forest

8 The word 'mangrove forest' in English identifies the kind of trees generally found in the forest, namely, mangrove or /ko:yka:y/ (โกงกาง) in common Thai. 


\section{Determinants of landscape classification: a summary}

The classification of landscape by coastal locals in Bang Khunsai centers on two main determinants: physical and cultural properties. Physical properties related to features villagers see or touch (such as shape, size, color, structure, etc.), or related to the natural characteristics are first and foremost used to indicate the basic semantic features or semantic components of terms for landscape. In addition, the semantic features that constitute the distinctive meaning of each term in some word-sets also refer to cultural properties such as utilization as raw material, or for some specific purposes (benefits). Terms for types of soil, for example, are classified into various distinct types based on physical properties including the cultural properties listed below.

\section{Examples of terms for soil}

/le:n/ (เลน)

+ muddy

- sticky

- able to be put into shape

+ sinking as being walked on

+ in water resource

+ suitable for mud-skiing

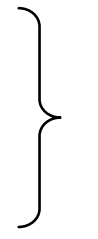

physical properties $\left\{\begin{array}{l}- \text { muddy } \\ + \text { sticky } \\ + \text { able to be put into shape } \\ - \text { sinking as being walked on } \\ + \text { in water resource }\end{array}\right.$

\} cultural properties /din nǐaw/ (ดินเหนียว)

$\{$ - suitable for mud-skiing
Physical properties reflect the villagers' perception of their natural surroundings which they may perceive differently from or similar to those who live in other areas. Cultural properties, on the other hand, reflect the utilization of landscape or natural resources by villagers. This is specific to individual communities. As shown in the examples earlier, the semantic features of terms for soil, which exist as cultural property, reflect the culture of this area in the utilization of muddy shore fishing resources by the locals. In this case, the villagers fish by means of mud-skiing. If we investigate the terms used for soils in different communities, we would probably find that the terms for soil may not possess any cultural property determinants in the semantic features of soil classification, or rather, they may but differently. Other cultural properties are evidenced in the semantic features of terms for types of sea and mangrove forest, reflecting the exploitation of marine resources and cultivation of the forest.

\section{Discussion and conclusion}

Landscape terms constitute a picture of the classification system used by Thai coastdwellers and also reflect their livelihood. Folk classification of landscape was observed for all particular domains identified in this study - sea, soil, water, and forest. Semantic features of words or terms for landscape reflect the villagers' perceptions of the geographic reality 
around them and their culture. In addition, the number of distinctions made within an individual domain and the degree of specialization within subtype reflects the degree of cultural interest and significance. For instance, the coastal locals label each feature of sea soil or nearby soil with a separate name (e.g. /le:n/ (เลน), /le:n k â:wtôm/ (เลนข้าวต้ม), /din da:n/ (ดินดาน), /sa:y k $\mathrm{k}^{\mathrm{h}} \mathrm{i}$ pèt/ (ทรายขี้เป็ด), and others) and thereby give it distinctive value. On the other hand, they rarely classify features of soil on the land, and this is reflected in the very limited number of terms used for land soil. As we have seen, only three terms for land soil were noted, namely /din/ (ดิน), /din kra:sá:/ (ดิน กระซ้า), and /sa:y/ (ทราย). This suggests that the coastal locals utilize the sea and coastal area more than the land. For these reasons, they pay less attention to soil on the land than to soil in the sea or nearby.

The most prominent vocabulary item of the coast-dwellers dealing with landscape is with reference to water. Seawater phenomena are especially identified and labeled because, significantly, the livelihoods of the coastal locals are directly dependent on the sea. The existence and usage by locals of numerous and complex words for identifying water phenomena and waves suggests that the coastal dwellers possess a great deal of specialized knowledge about local hydrology, a knowledge which enables them to wisely utilize the sea and avoid danger. Apart from this, it also refines our understanding of ecological features in coastal areas. Water terms also reflect the coastal villagers' daily routine related to the local environment, namely times for fishing.
Landscape terms used by coast-dwellers in different areas, or those used by different ethnic groups demand further investigation. From this study, it should be noted that locals of all persuasions utilize landscape-based words or terms, but a thorough understanding and use of the variety of landscape terms (e.g. terms for water and soil) is evident only to those who rely on and exploit the natural resources for their living. This has important implications for the further exploration of landscape terminology.

\section{References}

Bohnemeyer, J., N. Burenhult, N. J. Enfield and S. C. Levinson. 2004. Landscape terms and place names elicitation guide. In Field Manual Volume 9, edited by A. Majid, pp. 75-79. Nijmegen: Max Planck Institute for Psycholinguistics.

Burenhult, N. 2005. Landscape terms and toponyms in Jahai: A field report. Working Papers 51: 17-29.

Frake, Charles O. 1962. The Ethnographic Study of Cognitive System. In Anthropology and Human Behavior. Thomas Gladwin and William C. Sturtevant (eds.), pp 72-85. Washington D.C.: Anthropological Society of Washington. (Repr. in Tyler 1969: 28-41 and in Frake 1980: 1-17.)

Levinson, D. and M. Ember (eds.). 1996. Encyclopedia of Cultural Anthropology Vol.1. New York: Henry Holt \& company. 
Mark, D.M. and A.G. Turk. 2003.

Landscape categories in Yindjibarndi: ontology, environment, and language. Spatial Information Theory:

Foundations of Geographic

Information Science. Springer-Verlag, Berlin, pp. 28-45.

O'Connor, L. and P. C. Kroefges.

2008. The land remembers: landscape terms and place names in Lowland Chontal of Oaxaca, Mexico. Language Sciences 30.2-3: 291-315.

O’Meara, C. and J. Bohnemeyer. 2008. Complex landscape terms in Seri. Language Science 30. 2-3: 316-339.

Kamnuansin, Sunee. 2012. Eco Environmental Terminology and Folk Classification of Thai Coast-Dwellers: A Case Study in Bang Khunsai Subdistrict, Ban Laem District, Phetchabury Province. Doctoral dissertation, Linguistics, Mahidol University. 